\title{
A COMPARISON OF HEAT PERFORMANCE BETWEEN GREEN ROOFS ON CONCRETE AND GREEN ROOFS ON CORRUGATED ZINC
}

\author{
Sri Yuliani ${ }^{1^{*}}$, Gagoek Hardiman ${ }^{2}$, Erni Setyowati ${ }^{3}$ \\ ${ }^{1}$ Department of Architecture, Universitas Sebelas Maret, Jl. Ir Sutami 36A Surakarta, INDONESIA \\ ${ }^{2,3}$ Department of Architecture, Universitas Diponegoro, Jl. Prof. Soedarto Tembalang Semarang, INDONESIA \\ *Corresponding author; Email: sriyuliani71@ staff.uns.ac.id
}

\begin{abstract}
Green roofs are generally applied to concrete roofed buildings. This study compares the thermal performance of green roofs that occur in corrugated concrete and zinc to expand green roof innovation. The study experimented on a method using the 2011 Ecotect computer simulation. The results showed that the difference in temperature reduction in corrugated zinc was higher than in concrete. Changes in the heat outside the roof space on both have a number that has a relatively small difference, but the difference in heat is visible in the inner space. Based on the thermal performance of the roof, the use of corrugated zinc roofs as the base of the green roof in the building could be an alternative green roof material besides concrete.
\end{abstract}

Keywords: Green roof; heat performance; concrete; corrugated zinc.

\section{INTRODUCTION}

Drawn on the tendency of green roof research at least two aspects dominate the focus of green roof research on a world scale, i.e., the criteria for building objects and determining research methods. Green roof research trends are influenced more by environmental and energy issues. This research attempts to expand the scientific discourse of architecture by comparing the materials used for green roofs with residential building objects.

The first tendency, the object of green roof research is often the focus of research on concrete roofed buildings. Concrete green roof research generally deals with commercial public buildings, such as hotels, malls, superblocks, or schools. This study presents an innovative green roof placed on the roof of a low-rise residential building with a location criterion of a high-density residential area in a tropical climate.

Second, many green roof studies use quantitative research methods. Based on the type of method, green roof research is carried out by means of experiments and computer simulations. Experimental research is research that presents experimental objects in real terms with a certain scale; whereas, computer simulations use virtual objects built on digital analysis software.

Based on practical considerations of the model and data processing process, this study focuses on the thermal performance of green roofs made of concrete and corrugated zinc using Ecotect 2011 simulations. In some previous green roof studies, software varies greatly including CFD, EnergyPlus, and other software (Yuliani et al., 2020), but few use Ecotect.
The study considers the condition of climate data in the city of Surakarta, Indonesia in the analysis tool in that the simulation results can be more accurate, as the city has a humid tropical climate. The research procedure compares the potential and constraints of the application of green roofs on concrete and corrugated zinc to determine the opportunities of green roofs on corrugated zinc. Such a comparison leads to green roof innovations that enrich the technique of implementing green roof base materials in tropical climates.

Simulation of the green roof by Envimet has been carried out by Ambrosini et al. in the scale of urban areas by considering the application of green roofs, showing a relatively small effect if only carried out on several buildings with a limited area in the metropolis because the climatic conditions of the region are still intensely dominating (Ambrosini et al., 2014), in line with (Carvalho et al., 2017; J. Scott MacIvor et al., 2016; Viecco et al., 2018). A previous study on the focus of a single building with energy considerations show that for buildings that are isolated green roofs do not provide a significant thermal impact, but for buildings that are not isolated, the thermal performance of green roofs is very beneficial for indoor and outdoor environments (HT Rakotondramiarana et al., 2015). Envimet software is also used in building green performance testing (Gaspari \& Fabbri, 2019). The background of this research is the impact of climate change by discussing the potential reduction in regional temperature through green elements in buildings to optimize and determine the most effective greening patterns as a solution to improve outdoor comfortable conditions. 
Other researchers use EnergyPlus (Chan, 2018; Gargari et al., 2016; Owrak et al., 2015) to evaluate the thermal performance of buildings. Similar studies using Energyplus demonstrate that the energy use of semi-intensive and intensive green roofs is $60-70 \%$ and $45-60 \%$ lower than black and white roofs. A well-insulated roof does not fully utilize the cooling effect of evapotranspiration, which is particularly noticeable when compared to high reflective white roofs (Silva et al., 2016).

Testing with CFD is used by several researchers (Aly et al., 2017; Ge et al., 2019; Gromke et al., 2015; Park et al., 2016; Qin et al., 2018; Rafael et al., 2018) aims specifically to focus on thermal dynamics through air movement in buildings both indoors and outdoors. Buildings that are commonly used are ones that have problems in high-density areas with public building objects.

Building roof research is important because the roof plays a role in building energy management and evaluation can be done with simulations like the previous studies (Carbone et al., 2014; Costanzo et al., 2016; Herrera et al., 2018; Stovin et al., 2017; Van Renterghem et al., 2013).

Some green roof research has been conducted with simulation methods. Apparently, there is still not much information obtained from researchers who use Ecotect, even though there is actually an analysis menu that can be processed through this software. Previous research also has a tendency to compare conventional roofed building models with concrete and green roofs placed on the top of the concrete as thermal coating elements, but information on the use of corrugated zinc has not yet been obtained. For this reason, this study presents an Ecotect simulation method that can be used as a comparison, by taking green roof building objects applied to corrugated concrete and zinc.

\section{METHODOLOGY}

The selection of models for evaluation through simulations considers the conditions of urban problems and the characteristics of residential buildings in dense residential areas. The basis for consideration of the selection of this model is that the research findings can later become models that present actual problems in that they can become architectural solutions in overcoming building and environmental problems. The determination of the model establishes an existing residential building built in a dense low-floor residential area with a concrete roof and the corrugated zinc roof. The section of the room under corrugated iron roof is analyzed by creating a partition that divides the room into two. The building model is presented in Ecotect software with two treatments, i.e., the roof of the existing building and the roof of a green-roofed building.

In the first stage, the model imported from Autodesk sketchup is imported into Ecotect in two versions i.e., the plant-free building model as shown in Figures 1, 2, and 3 including the floor plan and the building view. The second version, a building model with plants that includes a floor plan and looks like 4, 5 , and 6. Both versions can be presented in two dimensions or three dimensions. The building model identified the characteristics of the material used, area, and position in detail.

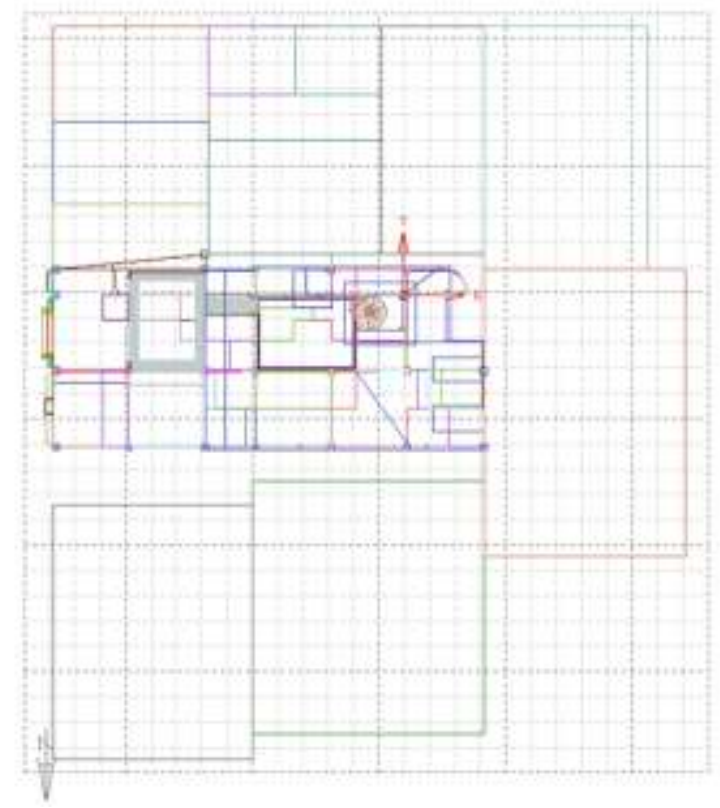

Fig. 1. Building Plan without Plants in the Area around the Object.

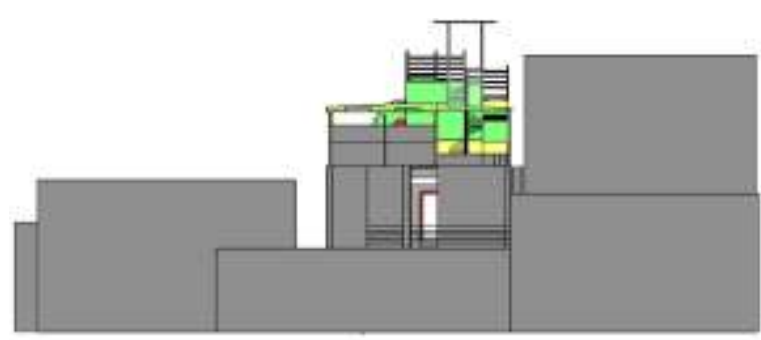

Fig. 2. The Southbound View of Buildings without Plants

The second stage, analyzing the simulation results using statistical processing by comparing the tested variables include one dependent variable i.e., temperature and two dependent variables i.e., the green roof on concrete and corrugated zinc measured in categories (Creswell, 2014). Evaluation of thermal performance was through simulation and calculation stages with Microsoft Excel and Origin statistical software. The results of both simulations are compared, and conclusions are related to the corrugated zinc roof opportunity. Thermal analysis 
begins by inserting Surakarta City climate data. At this stage, the study received information on heat changes that occur under two conditions of green roofs both inside and outside, during one year in the dry and rainy seasons within 24 hours.

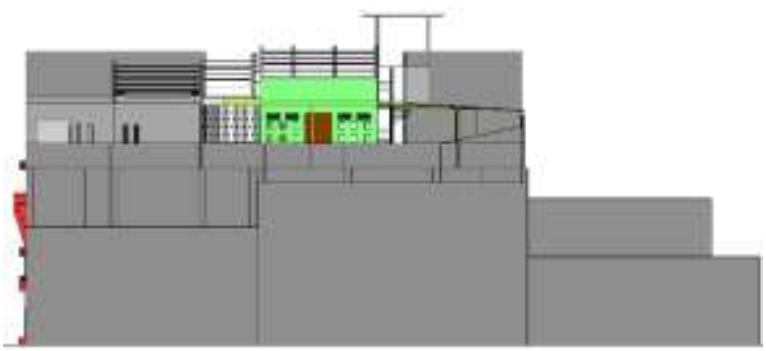

Fig. 3. The Northbound View of Buildings without Plants

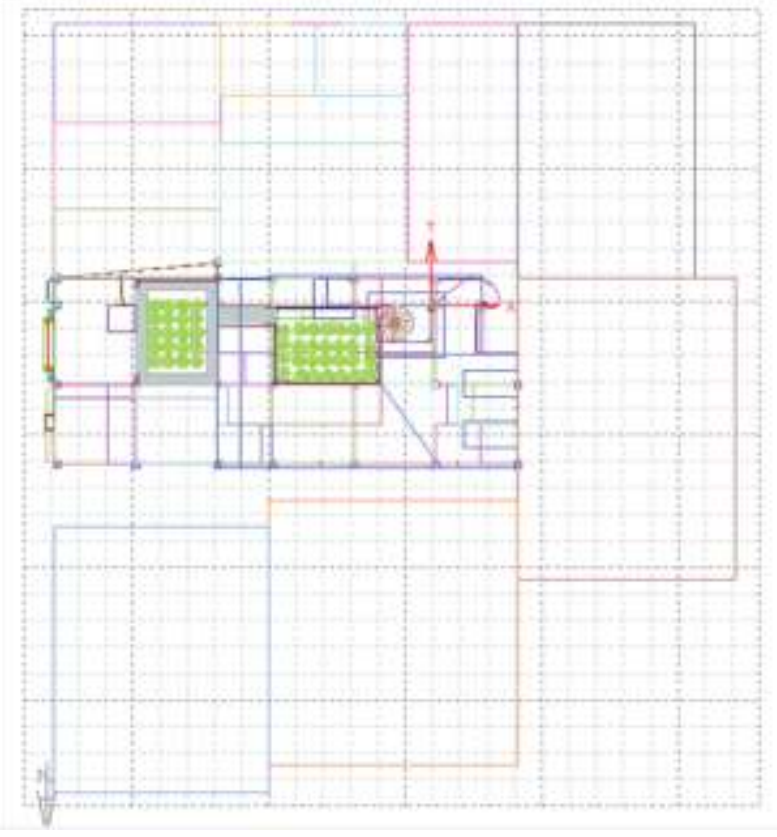

Fig. 4. Building Plan with Plants in the Area Around the Object

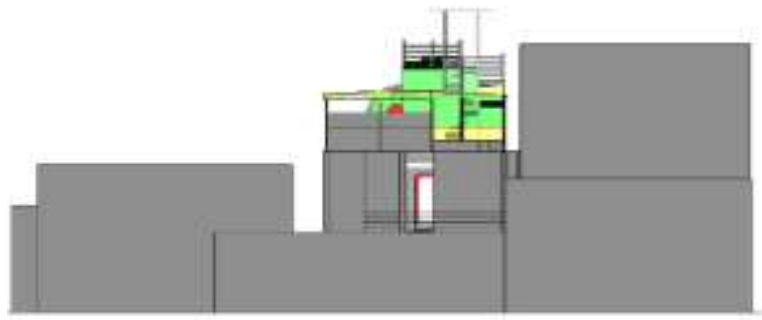

Fig. 5. The Southbound View of Buildings with Plants

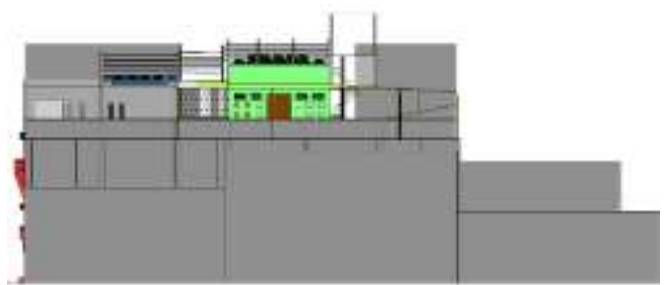

Fig. 6. The Northbound View of Buildings with Plants
The third step, analyzing simulation data through comparative statistics with Microsoft Excel and OriginLab, to get a comparative picture as a basis for determining the conclusions from the results of research on the opportunities of green roofs on corrugated zinc.

\section{RESULTS AND DISCUSSION}

Simulation results show that there is a significant reduction in heat to the application of green elements on corrugated or corrugated zinc roofs. Both of the green roof model used peanut plant on the concrete and corrugated zinc roofs.

\section{Roof without plants}

Model of residential building without plants is visualized in Figure 7 projected in the path of the solar orbit throughout the year. The mean radiant temperature presentation is presented in the extreme months of the dry and rainy seasons, normally in January and October. Figure 8 shows the visualization of heat dynamics occurring on a non-planted concrete roof in October as the hot peak month in the dry season. Figure 9 illustrates the change in heat on concrete roofs without plants in January. Figure 10 is a simulation result of thermal analysis on corrugated zinc roofs in October in the dry season and January in the rainy season as shown in Figure 11. The simulation results are summarized in Table 1 , which explains the material criteria, the extent to the value of Roof Thermal Transfer Value (RTTV). Overall, calculation in buildings without plants obtained the value of Overall Thermal Transfer Value (OTTV) in Table 2 with the results compared to the energy efficiency benchmarks.

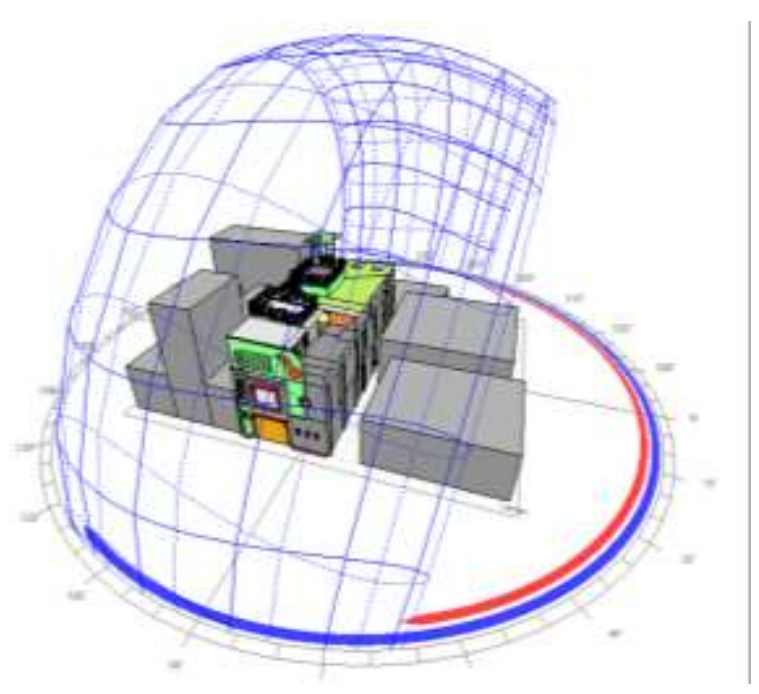

Fig. 7. Plantless Model 


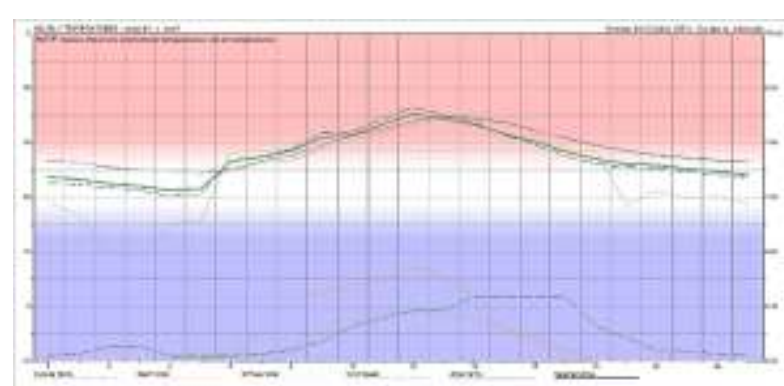

Fig. 8. Concrete roof in October

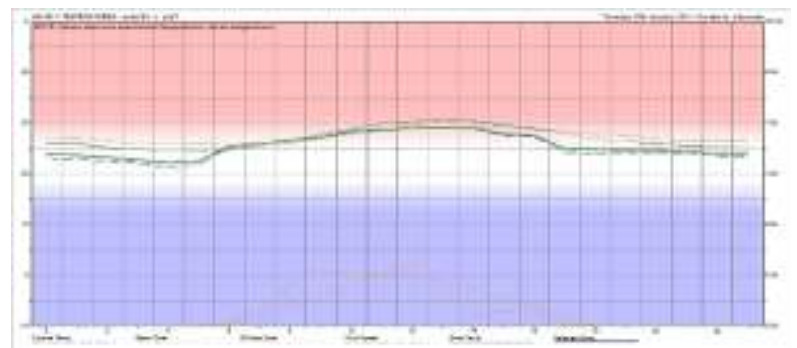

Fig. 9. Concrete roof in January

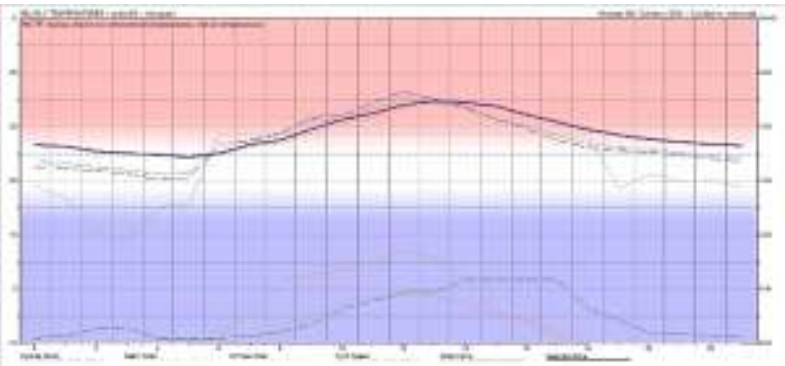

Fig. 10. Corrugated zinc roof in October

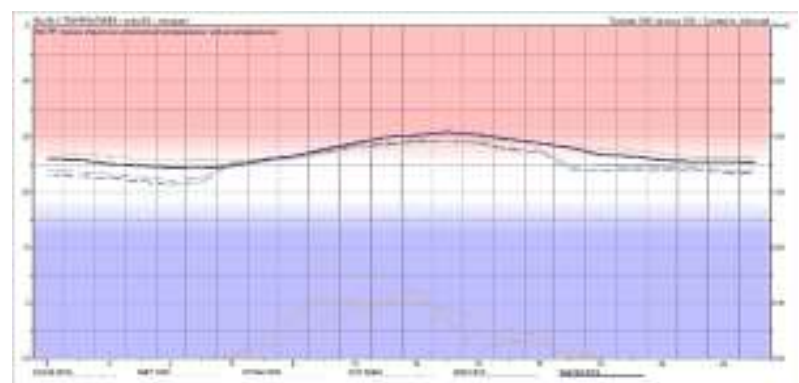

Fig. 11. Corrugated Zinc Roof in January

Table 1. Calculation of RTTV on Plantless model

\begin{tabular}{llcc}
\hline Component & Zinc roof & $\begin{array}{c}\text { Concrete } \\
\text { roof }\end{array}$ & Unit \\
\hline$\alpha$ (surface absorptions) & 0.26 & 0.47 & \\
$\mathrm{U}_{\mathrm{w}}(\mathrm{U}$-value on roof) & 5.05 & 3.69 & $\mathrm{~W} / \mathrm{m}^{2} \mathrm{~K}$ \\
$\mathrm{~A}_{\mathrm{w}}($ Area) & 23.99 & 12.00 & $\mathrm{~m}^{2}$ \\
$\mathrm{~A}_{\mathrm{wn}} / \mathrm{A}_{\mathrm{w}}$ & 0.63 & 0.32 & \\
Weight/area & 2.10 & 283.85 & $\mathrm{~kg} / \mathrm{m}^{2}$ \\
TD & 24 & 16 & $\mathrm{~K}$ \\
RTTV opaque (conductive) & 19.90 & 16.43 & $\mathrm{~W} / \mathrm{m}^{2}$ \\
$\Delta \mathrm{T}$ (temperature difference) & 5 & & $\mathrm{~K}$ \\
RTTV opague (conductive) & 0.00 & 0.00 & $\mathrm{~W} / \mathrm{m}^{2}$ \\
SF & 316 & & \\
Total Area & 37.99 & & $\mathrm{~m}{ }^{2}$ \\
Roof RTTV & 39.54 & & $\mathrm{~W} / \mathrm{m}^{2}$ \\
\hline
\end{tabular}

Table 2. OTTV Calculations

\begin{tabular}{lcccc}
\hline \multicolumn{1}{c}{ Section } & $\begin{array}{c}\text { Partial } \\
\text { OTTV }\end{array}$ & $\begin{array}{c}\text { Area of the } \\
\text { envelope }\end{array}$ & $\begin{array}{c}\text { Thermal } \\
\text { Transmittance }\end{array}$ & WWR \\
\hline East façade & 16.78 & 20.87 & 350.13 & 0.07 \\
North façade & 26.27 & 24.51 & 643.84 & 0.06 \\
West façade & 17.79 & 12.11 & 215.30 & 0.01 \\
South façade & 29.36 & 27.02 & 793.24 & 0.06 \\
Total & & 63.63 & $1,652.38$ & Watt $/ \mathrm{m}^{2}$ \\
\hline
\end{tabular}

The value of OTTV as a whole $=\frac{1,652,38 \text { Watt }}{63,63 \mathrm{~m} 2}=$ $25.97 \mathrm{~W} / \mathrm{m}^{2}$

Based on SNI 6389-2011 concerning energy conservation of building envelope in buildings, 25.97 $\mathrm{W} / \mathrm{m}^{2}$ less than $35 \mathrm{~W} / \mathrm{m}^{2}$ so the building has an energy saving category.

RTTV opaque of $39.54 \mathrm{~W} / \mathrm{m}^{2}$ and RTTV skylight being non-existent, the total number of RTTV objects without plants equals to $39.54 \mathrm{~W} / \mathrm{m}^{2}$. Based on SNI 6389-2011 on energy conservation of building envelope, $39.54 \mathrm{~W} / \mathrm{m}^{2}$ is more than $35 \mathrm{~W} / \mathrm{m}^{2}$ so the building has a category of not saving energy. As for the U-value of the roof with a weight per unit area of $91.41 \mathrm{~m} 2$ the average $U$-value is 4.64 and the maximum U-value is 0.80. Based on SNI 6389-2011 concerning energy conservation of building envelope in buildings, it includes the category of roof buildings that are not energy efficient.

\section{Green Roofs}

As in the first version of the model, for this second model, the results obtained from the modeling in Figure 12 for the position of the model in solar orbit throughout the year. The summary of simulation results is presented in a representative manner based on the season, i.e., the dry season and the rainy season: the dry season (Figure 13) for green roofs on concrete and (Figure 15) for green roofs on corrugated zinc. On the other hand, in the rainy season it is presented in January for concrete roofs (Figure 14) and for green roofs on corrugated zinc (Figure 16).

The analysis of OTTV and RTTV calculations are presented in Tables 3 and 4 . The resulting figures show a corroborating difference that the green roof has the benefit of reducing temperatures as the findings of previous researchers with various analysis software applications, such as ones in the literature review description. 


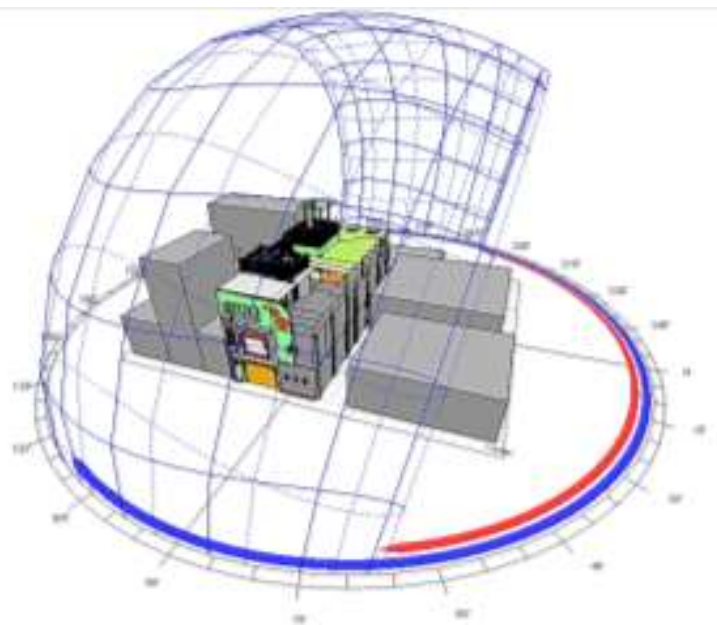

Fig. 12. Model Building Planted

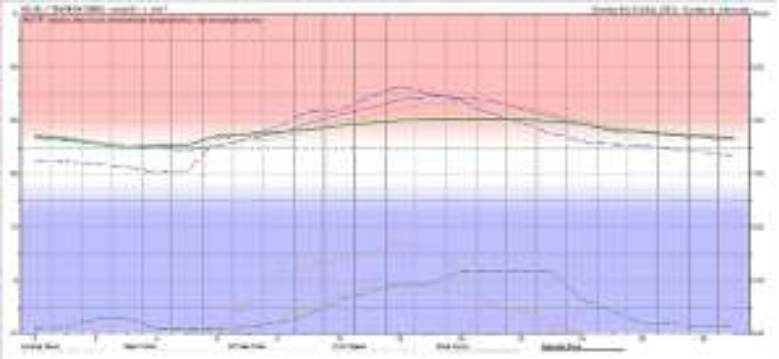

Fig. 13. Green Roof on Concrete in October

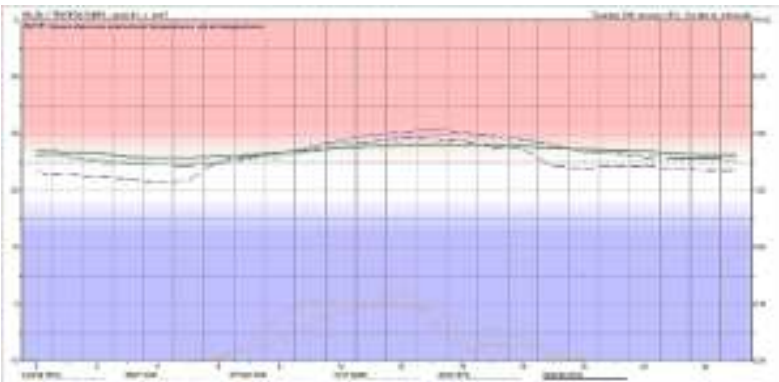

Fig. 14. Green Roof on Concrete in January

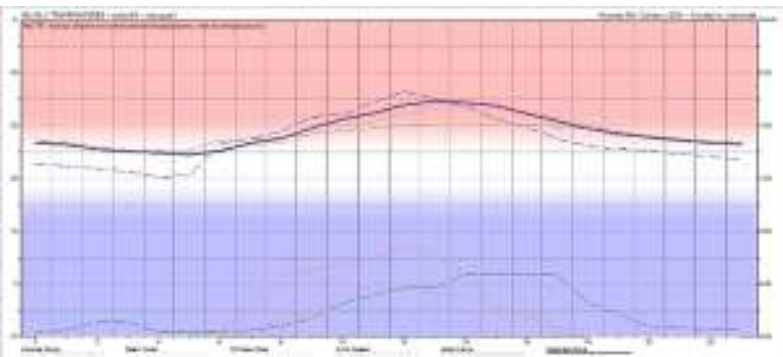

Fig. 15. Green Roof on Corrugated zinc in October

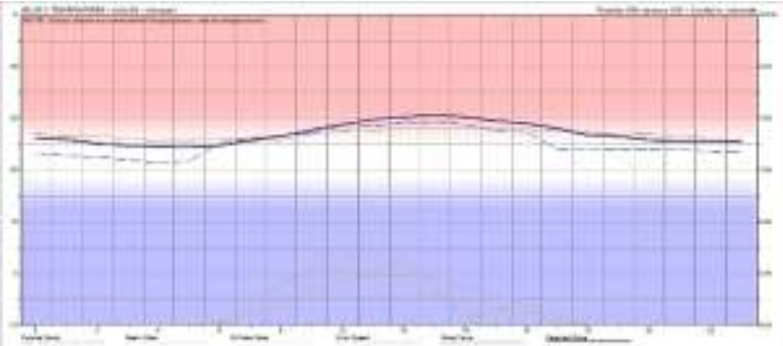

Fig. 16. Green Roof on Corrugated zinc in January
Table 3. Calculation of RTTV on Green Roofs

\begin{tabular}{llll}
\hline Component & $\begin{array}{c}\text { Green } \\
\text { roof - Zinc }\end{array}$ & $\begin{array}{c}\text { Green roof - } \\
\text { Concrete }\end{array}$ & Unit \\
\hline $\begin{array}{l}\alpha \text { (surface absorption, } \\
\text { with plant) }\end{array}$ & 0.88 & 0.88 & \\
U-value(include plant) & 0.62 & 0.57 & $\mathrm{~W} / \mathrm{m} 2 \mathrm{~K}$ \\
Aw (area) & 23.99 & 12.00 & $\mathrm{~m} 2$ \\
Awn/ $\sum$ Aw & 0.19 & 0.32 & \\
Weight/ area & $1,708.92$ & $2,059.87$ & $\mathrm{~kg} / \mathrm{m} 2$ \\
TDek & 16 & 16 & $\mathrm{~K}$ \\
RTTV opaque & 1.62 & 2.54 & $\mathrm{~W} / \mathrm{m} 2$ \\
(conductive) & 316 & & \\
SF & 37,99 & & $\mathrm{~m} 2$ \\
Total Area & 21,44 & & $\mathrm{~W} / \mathrm{m} 2$ \\
Roof RTTV & & & \\
\hline
\end{tabular}

Table 4. OTTV Calculations

\begin{tabular}{lcccc}
\hline \multicolumn{1}{c}{ Position } & $\begin{array}{c}\text { Partial } \\
\text { OTTV }\end{array}$ & $\begin{array}{c}\text { Area of the } \\
\text { envelope }\end{array}$ & $\begin{array}{c}\text { Thermal } \\
\text { Transmittance }\end{array}$ & WWR \\
\hline East façade & 16.78 & 20.87 & 350.13 & 0.07 \\
North façade & 26.27 & 24.51 & 643.84 & 0.06 \\
West façade & 17.79 & 12.11 & 215.30 & 0.01 \\
South façade & 29.36 & 27.02 & 793.24 & 0.06 \\
Total & & 63.63 & $1,652.38$ & \\
\hline
\end{tabular}

Total OTTV $=1,652.38 / 63.63=25.97 \mathrm{Watt} / \mathrm{m}^{2}$

Calculation of maximum roof U-value, with a weight per unit area of 1,022.01 and U-value averaging $2.69 \mathrm{~W} / \mathrm{m}^{2}$, then maximum U-value is 1.2 $\mathrm{W} / \mathrm{m}^{2}$. RTTV calculations with the results are 21.44 W/m2. Based on SNI 6389: 2011 concerning energy conservation of building envelope in buildings, the values of OTTV and RTTV are below $35 \mathrm{Watt} / \mathrm{m}^{2}$ have energy efficiency values in buildings. The thermal performance of buildings in both roof models is compared with various criteria.

The discussion begins by using the criteria for seasons in tropical climates, the difference in room temperature in the dry season shows that the peak heat occurs at 12.00-13.00 as shown in Figure. 17 and 18, where the highest temperature in the room is experienced by corrugated zinc roof without plants and the lowest temperature on the planted concrete roof.

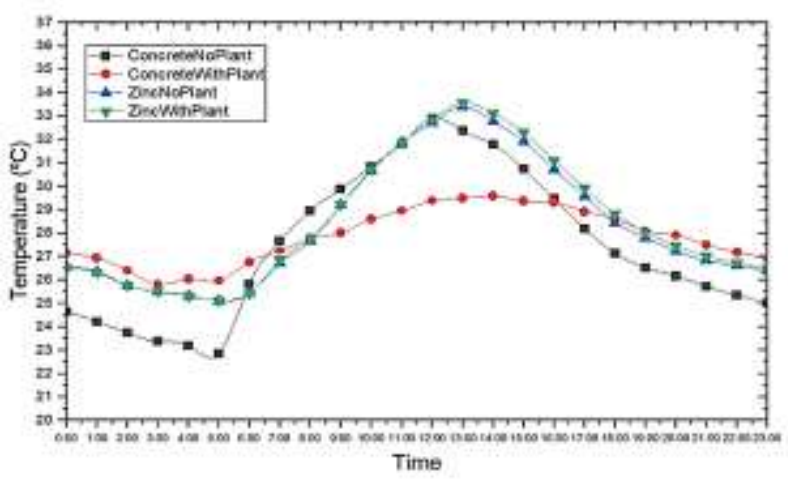

Fig. 17. Dry season inside temperature 


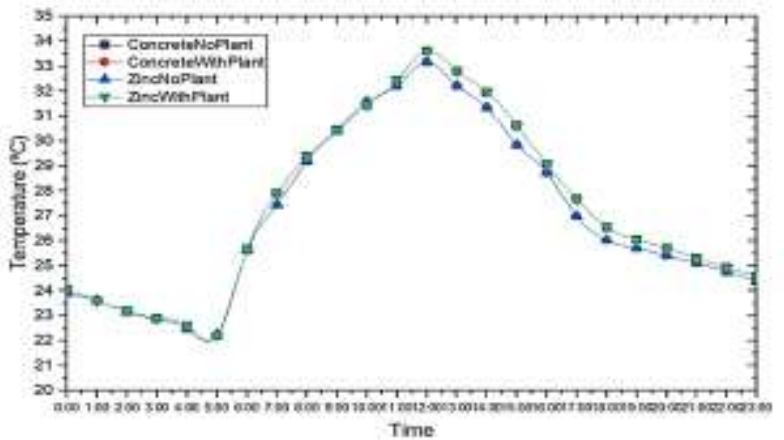

Fig. 18. Dry season outside temperature

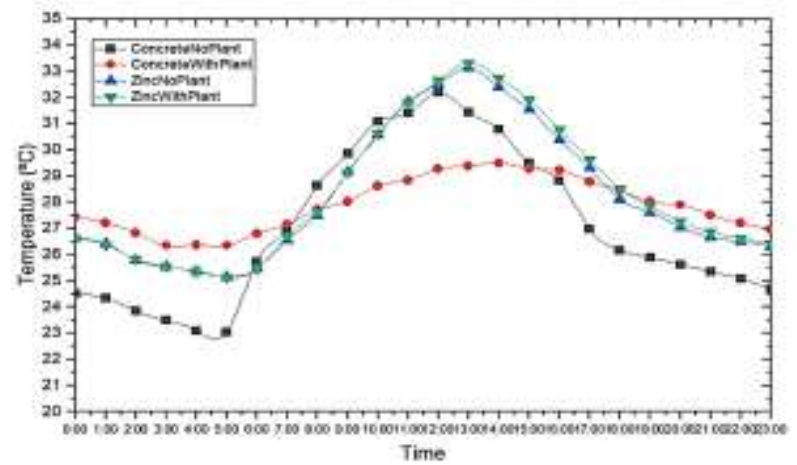

Fig. 19. Wet Season Inside Temperature

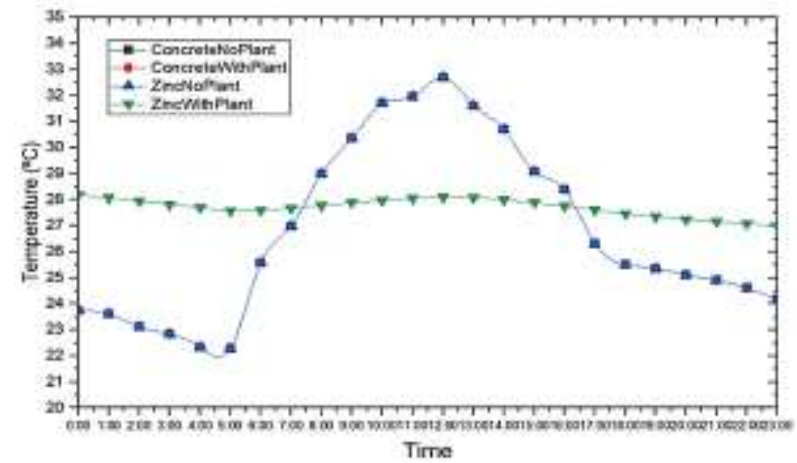

Fig. 20. Wet Season Outside Temperature

The highest temperature ratio achieved in the two models in Figure 21, shows that the trend in indoor conditions, corrugated zinc roof at high temperatures, but when it gets plant applications, corrugated zinc roof experiences a small temperature drop adrift with concrete roof, except for April. While in the outer space in Figure 22, a decrease in temperature due to the application of a green roof on corrugated zinc tends to show a graph that approaches the temperature trend on a concrete roof.

The discussion on the minimum temperature for both models shows that in the inner room, corrugated zinc roof has the fastest response to cold as in Figure 23. This condition has similarities with the dynamics of temperature changes in the outside room, as corrugated zinc has the fastest temperature decrease, as in Figure 24. As for concrete roofs, although there are relatively significant temperature changes in indoor and outdoor spaces, the temperature change graph shows lower changes compared to corrugated zinc roofs.

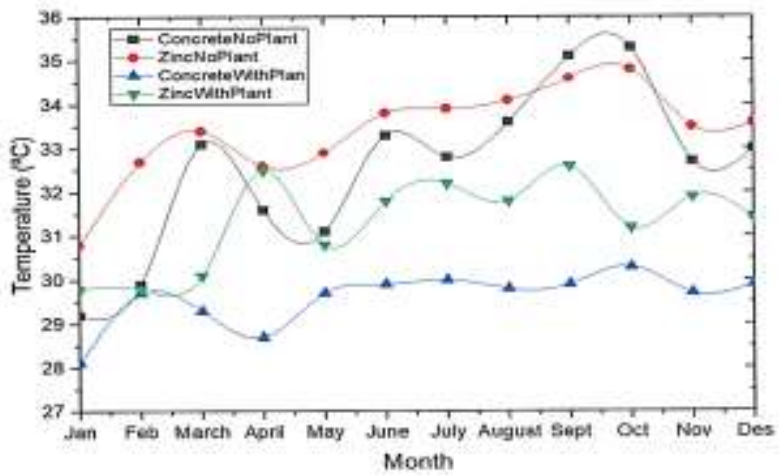

Fig. 21. Maximum Temperature of Inside

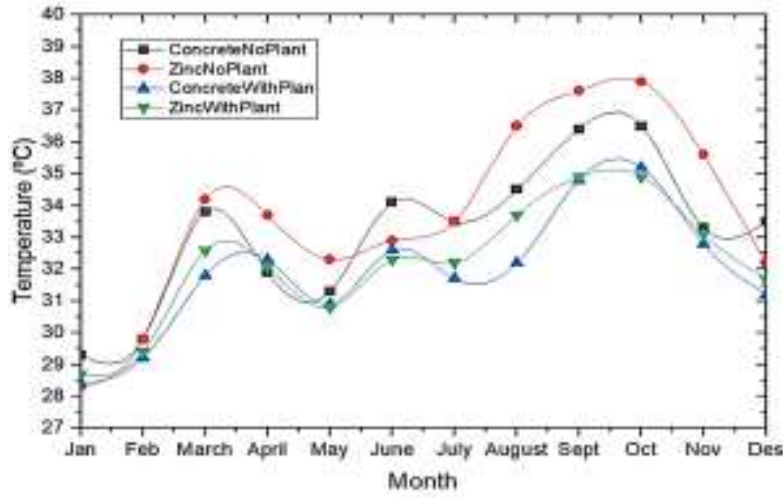

Fig. 22. Maximum Temperature of Outside

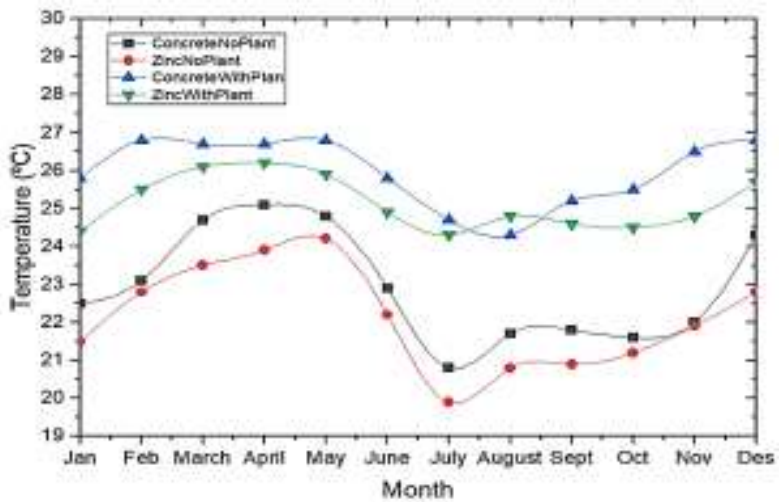

Fig. 23. Minimum Temperature of Inside

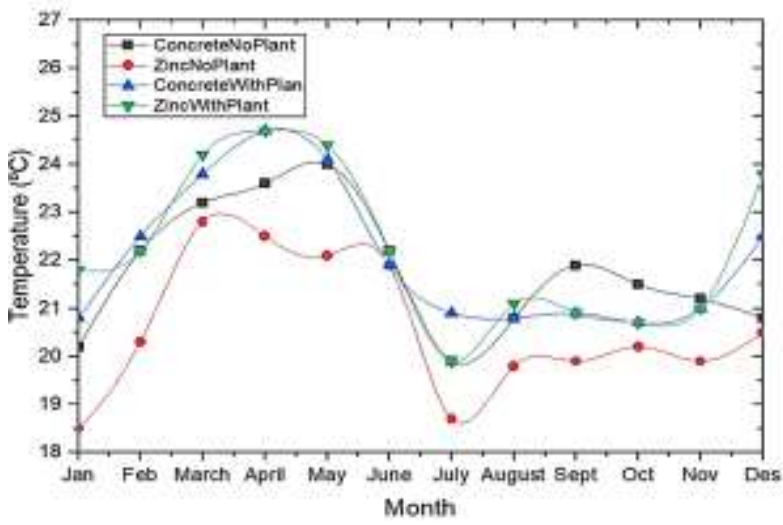

Fig. 24. Minimum Temperature of Outside 
Research on the experimental model of low-rise dwelling in urban areas with humid tropical climate through simulations using Ecotect 2011 software, resulted in the finding of differences between RTTV values and $\mathrm{U}$-values on the planted and non-planted roofs. Building RTTV is one of the determinants of building efficiency in several simulation tests that have been carried out on different objects (Carbone et al., 2014; Costanzo et al., 2016; Herrera et al., 2018; Stovin et al., 2017; Van Renterghem et al., 2013). The simulation test is actually not the only research method, but for the purpose of discussing energy based on obtaining RTTV values, this method feels very helpful because it is more efficient in terms of time and energy.

An important finding obtained from this study is the difference in the value of RTTV and OTTV in green roofed buildings with green or conventional roofed buildings. A significant reduction in numbers reaching almost $50 \%$ is a very useful finding. The decrease in RTTV was mainly obtained by the presence of a green element placed on the roof, so that with the decrease in the value of RTTV into an energy-efficient building according to SNI 6389-2011 standard. This study corroborates several findings that have been made by other researchers related to building energy efficiency (Altomonte et al., 2017; Baraldi et al., 2019; Shafique et al., 2018).

The benefits to the environment can be obtained from this study because the value of heat circulation that can be reduced, this study reinforces previous research on efforts to reduce regional heat or urban heat island (Ambrosini et al., 2014; Carvalho et al., 2017; MacIvor et al., 2016; Vera et al., 2018).

The simulation results show a very satisfying difference from the U-value between corrugated zinc roof, concrete roof and planting roof (Figure 25).

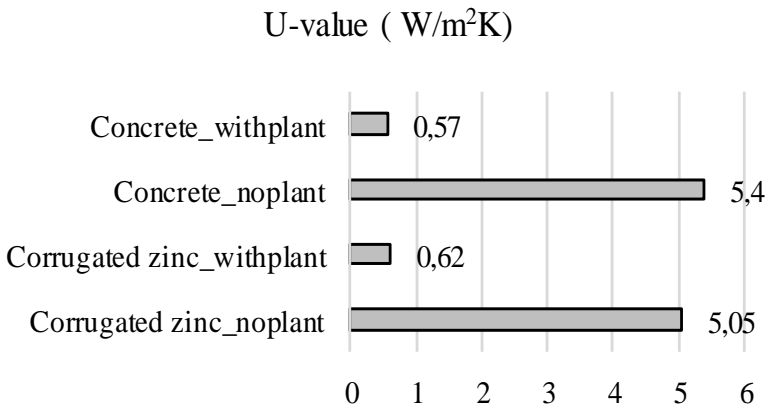

Fig. 25. Comparison of Uvalue on the roof of the model

U-values on planted roofs provide substantial reductions, on average reaching more than $80 \%$. For corrugated zinc roof from $5.05 \mathrm{~W} / \mathrm{m}^{2} \mathrm{~K}$ down to 0.62 $\mathrm{W} / \mathrm{m}^{2} \mathrm{~K}$, which means a decrease for up to $87.72 \%$.
Meanwhile, the comparison between concrete roofs and planted concrete roofs has decreased to $89.44 \%$. The results of this simulation test concluded that there was a significantly high decrease, in that further research was needed through experiments. Research with Ecotect simulation turned out to be able to show the evaluation of thermal performance in buildings with green roof applications, as well as research with other software simulations i.e., Envimet (Ambrosini et al., 2014; Gaspari \& Fabbri, 2019; Rakotondramiarana et al., 2015), Energyplus Chan, 2018; Gargari et al., 2016; Owrak et al., 2015), CFD (Aly et al., 2017; Ge et al., 2019; Gromke et al., 2015; Park et al., 2016; Qin et al., 2018; Rafael et al., 2018).

\section{CONCLUSION}

Green roofs in low-rise residential buildings could reduce heat both indoors and outdoors in a simulation test using Ecotect 2011 software. The results obtained in the research analysis concluded that the temperature difference that can be reduced by plant elements on the roof was also able to provide a decrease RTTV value of the building. Comparison of RTTV calculations obtained on a roof without plants which is $39.54 \mathrm{~W} / \mathrm{m}^{2}$ decreased to $21.44 \mathrm{~W} / \mathrm{m}^{2}$ with a gap of $18.1 \mathrm{~W} / \mathrm{m}^{2}$ as a quite significant gap. Whereas based on SNI 6389-2011, energy efficient building category is required to have a maximum RTTV 35 $\mathrm{W} / \mathrm{m}^{2}$ in that the green roof on the residential building in the experimental model carried out is influential in the energy efficiency of the building.

Research on green roofs in low-rise residential buildings in urban areas in the humid tropics with the Ecotect simulation test method reveals findings that are very useful for energy management in buildings. However, in conducting research with this simulation test method it was found that there were some obstacles in entering material data that were possible to have different values between the data from simulations and real data in the field. Therefore, the study recommends the need for further evaluations in experimental methods with measurements in the field.

\section{ACKNOWLEDGMENT}

The researcher would like to thank the Diponegoro University's Architecture and Urban Science Doctoral Program who has provided a reference network and facilities for conducting the study. The study was funded by the Sebelas Maret University Research and Community Service Institute through the 2020 PNBP Fund Research Competition Grant of the Doctoral Dissertation Research Scheme Number 452/UN27.21/PN/2020. 


\section{REFERENCES}

Altomonte, S., Schiavon, S., Kent, M. G., \& Brager, G. (2017). Indoor environmental quality and occupant satisfaction in green-certified buildings. Building Research and Information, 1-20. https://doi.org/10.1080/09613218.2018.1383715

Aly, A. M., Chokwitthaya, C., \& Poche, R. (2017). Retro fi tting building roofs with aerodynamic features and solar panels to reduce hurricane damage and enhance eco-friendly energy production. Sustainable Cities and Society, 35, 581-593. https://doi.org/10.1016/j.scs.2017.09. 002

Ambrosini, D., Galli, G., Mancini, B., Nardi, I., \& Sfarra, S. (2014). Evaluating Mitigation Effects of Urban Heat Islands in a Historical Small Center with the ENVI-Met ${ }^{\circledR}$ Climate Model. 7013-7029. https://doi.org/10.3390/su6107013

Baraldi, R., Neri, L., Costa, F., Facini, O., Rapparini, F., \& Carriero, G. (2019). Ecophysiological and micromorphological characterization of green roof vegetation for urban mitigation. Urban Forestry and Urban Greening. https://doi.org/ 10.1016/j.ufug.2018.03.002

Carbone, M., Garofalo, G., Nigro, G., \& Piro, P. (2014). A conceptual model for predicting hydraulic behaviour of a green roof. Procedia Engineering, 70, 266-274. https://doi.org/10. 1016/j.proeng.2014.02.030

Carvalho, D., Martins, H., Marta-almeida, M., Rocha, A., \& Borrego, C. (2017). Urban Climate Urban resilience to future urban heat waves under a climate change scenario: A case study for Porto urban area (Portugal). Urban Climate, 19, 1-27. https://doi.org/10.1016/j.uclim.2016.11.005

Costanzo, V., Evola, G., \& Marletta, L. (2016). Energy savings in buildings or UHI mitigation? Comparison between green roofs and cool roofs. Energy and Buildings, 114, 247-255. https://doi.org/10.1016/j.enbuild.2015.04.053

Creswell, J. W. (2014). Research Design: Qualitative, Quantitative, and Mixed Method. In Research design Qualitative quantitative and mixed methods approaches. https://doi.org/10.1007/ s13398-014-0173-7.2

Gaspari, J., \& Fabbri, K. (2019). Greening Actions and the Related Potential Impacts on Outdoor Comfort in a Dense Built Environment. IOP Conference Series: Earth and Environmental Science, 290(1). https://doi.org/10.1088/17551315/290/1/012163

Ge, Z., Xu, G., Poh, H. J., Ooi, C. C., \& Xing, X. (2019). CFD simulations of thermal comfort for naturally ventilated school buildings. IOP Conference Series: Earth and Environmental Science, 238(1). https://doi.org/10.1088/17551315/238/1/012073

Gromke, C., Blocken, B., Janssen, W., Merema, B., van Hooff, T., \& Timmermans, H. (2015). CFD analysis of transpirational cooling by vegetation: Case study for specific meteorological conditions during a heat wave in Arnhem, Netherlands. Building and Environment, 83, 11-26.

https://doi.org/10.1016/j.buildenv.2014.04.022

Herrera, J., Flamant, G., Gironás, J., Vera, S., Bonilla, C. A., Bustamante, W., \& Suárez, F. (2018). Using a hydrological model to simulate the performance and estimate the runoffcoefficient of green roofs in semiarid climates. Water (Switzerland), 10(2). https://doi.org/10.3390/w 10020198

MacIvor, J. S., Cadotte, M. W., Livingstone, S. W., Lundholm, J. T., \& Yasui, S. L. E. (2016). Phylogenetic ecology and the greening of cities. Journal of Applied Ecology, 53(5). https://doi. org/10.1111/1365-2664.12667

Park, S. J., Choi, W., Kim, J. J., Kim, M. J., Park, R. J., Han, K. S., \& Kang, G. (2016). Effects of building-roof cooling on the flow and dispersion of reactive pollutants in an idealized urban street canyon. Building and Environment, 109(2), 175-189. https://doi.org/10.1016/j.buildenv.2016.09.011

Qin, H., Hong, B., \& Jiang, R. (2018). Are green walls better options than green roofs for mitigating PM10 pollution? CFD simulations in urban street canyons. Sustainability (Switzerl and), 10(8). https://doi.org/10.3390/su10082833

Rafael, S., Vicente, B., Rodrigues, V., Miranda, A. I., Borrego, C., \& Lopes, M. (2018). Impacts of green infrastructures on aerodynamic fl ow and air quality in Porto's urban area. Atmospheric Environment, 190(July), 317-330. https://doi. org/10.1016/j.atmosenv.2018.07.044

Rakotondramiarana, H., Ranaivoarisoa, T., \& Morau, D. (2015). Dynamic Simulation of the Green Roofs Impact on Building Energy Performance, Case Study of Antananarivo, Madagascar. Buildings, 5(2). https://doi.org/10.3390/buildings5020497

Shafique, M., Kim, R., \& Rafiq, M. (2018). Green roof benefits, opportunities and challenges - A review. Renewable and Sustainable Energy Reviews, 90, 757-773. https://doi.org/10.1016/ j.rser.2018.04.006. 
Silva, C. M., Gomes, M. G., \& Silva, M. (2016). Green roofs energy performance in Mediterranean climate. Energy and Buildings, 116, 318-325. https://doi.org/10.1007/s12197-0169374-6.

Stovin, V., Vesuviano, G., \& De-Ville, S. (2017). Defining green roof detention performance. Urban Water Journal, 14(6), 574-588. https://doi. org/10.1080/1573062X.2015.1049279.
Van Renterghem, T., Hornikx, M., Forssen, J., \& Botteldooren, D. (2013). The potential of building envelope greening to achieve quietness. Building and Environment, 61, 34-44. https://doi.org/10.1016/j.buildenv.2012.12.001.

Vera, S., Pinto, C., Tabares-Velasco, P. C., \& Bustamante, W. (2018). A critical review of heat and mass transfer in vegetative roof models used in building energy and urban enviroment simulation tools. In Applied Energy (232). 